\title{
Potentiation of neuritogenic activity of medicinal mushrooms in rat pheochromocytoma cells
}

Syntyche Ling-Sing Seow ${ }^{1,2}$, Murali Naidu ${ }^{1,3^{*}}$, Pamela David ${ }^{1,3}$, Kah-Hui Wong $^{1,3}$ and Vikineswary Sabaratnam ${ }^{1,2}$

\begin{abstract}
Background: Senescence of the neurons is believed to be a focal factor in the development of age-related neurodegenerative diseases such as Alzheimer's disease. Diminutions in the levels of nerve growth factor (NGF) lead to major declines in brain cell performance. Functional foods, believed to mitigate this deficiency, will be reaching a plateau in the near future market of alternative and preventive medicine. In the search for neuroactive compounds that mimic the NGF activity for the prevention of neurodegenerative diseases, the potential medicinal values of culinary and medicinal mushrooms attract intense interest.

Methods: Cytotoxic effects of aqueous extracts of three medicinal mushrooms basidiocarps, Ganoderma lucidum, Ganoderma neo-japonicum and Grifola frondosa towards rat pheochromocytoma (PC-12) cells were determined by 3-(4,5-dimethythiazol-2-yl)-2,5-diphenyltetrazolium bromide (MTT) assay. The potentiation of neuritogenic activity was assessed by neurite outgrowth stimulation assay. Involvement of cellular signaling pathways, mitogen-activated protein kinase kinase/extracellular signal-regulated kinase (MEK/ERK1/2) and phosphoinositide-3-kinase/protein kinase B (PI3K/Akt) in mushrooms-stimulated neuritogenesis were examined by using specific pharmacological inhibitors. Alteration of neuronal morphology by inhibitors was visualized by immunofluorescence staining of the neurofilament.
\end{abstract}

Results: All the aqueous extracts tested caused a marked stimulation of neuritogenesis with no detectable cytotoxic effects towards PC-12 cells. The aqueous extract of G. neo-japonicum triggered maximal stimulation of neurite outgrowth at a lower concentration $(50 \mu \mathrm{g} / \mathrm{ml})$ with $14.22 \pm 0.43 \%$ of neurite-bearing cells, compared to $\mathrm{G}$. lucidum and $\mathrm{G}$. frondosa that act at a higher concentration $(75 \mu \mathrm{g} / \mathrm{ml})$, with $12.61 \pm 0.11 \%$ and $12.07 \pm 0.46 \%$ of neurite-bearing cells, respectively. The activation of MEK/ERK1/2 and PI3K/Akt signaling pathways were necessary for the NGF and aqueous extracts to promote neuritogenesis.

Conclusions: Ganoderma lucidum, G. neo-japonicum and G. frondosa may contain NGF-like bioactive compound(s) for maintaining and regenerating the neuronal communications network. The present study reports the first evidence of the neuritogenic effects of aqueous extracts of basidiocarps of $G$. neo-japonicum in-vitro and showed the involvement of MEK/ERK1/2 and P13K/Akt signaling pathways for neuritogenesis in PC-12 cells.

Keywords: Ganoderma lucidum, Ganoderma neo-japonicum, Grifola frondosa, Neuritogenesis, Neurodegenerative disease, Nerve growth factor, MEK/ERK signaling pathway, PI3K/Akt signaling pathway

\footnotetext{
* Correspondence: murali_naidu@um.edu.my

${ }^{1}$ Mushroom Research Centre, Faculty of Science, University of Malaya, 50603

Kuala Lumpur, Malaysia

${ }^{3}$ Department of Anatomy, Faculty of Medicine, University of Malaya, 50603

Kuala Lumpur, Malaysia

Full list of author information is available at the end of the article
} 


\section{Background}

According to the World Health Organization (WHO), nearly 35.6 million people worldwide live with dementia in 2010. The number is expected to double by 2030 (65.7 million) and more than triple by 2050 (115.4 million) [1]. Dementia is a brain function syndrome characterized by a cluster of symptoms and signs manifested by difficulties in memory, disturbances in language, psychological and psychiatric changes, and impairments in activities of daily living. Alzheimer's disease is one form of dementia that gradually gets worse over time. It affects memory, thinking, and behaviour [2].

Neuritogenic activity is one of the focuses of the study on the preventive and therapeutic effects of neurodegenerative diseases. Neuritogenic substances hold the promise of therapeutic efficacy in the treatment of neuronal injuries by the virtue of their ability to stimulate outgrowth of neurites from neuronal cells [3]. Recent reports showed that many extracts or compounds from natural sources possessed significant neuritogenic activity in vitro and in vivo, included hericenones and erinacines from Hericium erinaceus (lion's mane mushroom) [4] and curcumin from Curcuma longa [5].

Nerve growth factor has potent biological activities such as promoting neuronal survival and neuritogenesis [6]. It is targeted as a potential therapeutic drug for the treatment of neurodegenerative disorders $[7,8]$. However, NGF is unstable and is unable to cross blood-brain barrier because of its high molecular polypeptide [9]. Hence, the potential medicinal values of culinary and medicinal mushrooms have attracted intense interest in the search for pharmacological compounds that mimic the NGF activity in the prevention of neurodegenerative diseases. Medicinal mushrooms have a long and rich history of use as mycomedicinals $[10,11]$. Extracts of medicinal mushrooms have long been an important part of traditional oriental medicines. Many studies reported that edible and medicinal mushrooms possessed neuritogenic effects. In the previous studies, the neuritogenic and nerve regeneration effects of Hericium erinaceus (Bull.:Fr.) Pers. in in vitro and in vivo [12-14], the sclerotium of Lignosus rhinocerotis (Cooke) Ryvarden (tiger's milk mushroom) [15] and Pleurotus giganteus (Berk.) Karunarathna \& K.D. Hyde (morning glory mushroom) [16] were documented.

The genus Ganoderma is a popular medicinal mushroom, and is used in traditional Chinese medicine (TCM) as a tonic and sedative in Asian countries. For over two millennia its use is documented in countries including China, Japan and Korea [17,18]. Ganoderma lucidum (Curtis: Fr.) P. Karst, called "Lingzhi" in Chinese and "Reishi" in Japanese, is one of the most commonly used mushroom by TCM in Asia [17]. According to "Shennong Ben Cao Jing", a Chinese book on agriculture and medicinal plants (300
BC $-200 \mathrm{AC}$ ), Lingzhi is classified into six categories based on colour, which are red, yellow, black, white, green and purple. Ganoderma lucidum is the most common red Lingzhi and Ganoderma neo-japonicum Imazeki is categorized as purple Lingzhi. Ganoderma neo-japonicum is found in Mainland China, Japan and Taiwan, and grows saprotrophically on dead hardwoods or bamboos [19]. In Malaysia, G. neo-japonicum grows on bamboo. A water infusion is used by the indigenous folks as medicine and a tonic to strengthen the body (unpublished data). Grifola frondosa (Dicks.) Gray, also known by its Japanese name "Maitake" which means "dancing mushroom", has been used as a health food for centuries in China and Japan. Maitake is a delicious culinary mushroom and also valued for its medicinal properties. Studies have shown that G. lucidum [18] and G. frondosa [20] possessed neuritogenic effects in preventing and treating neurological disorders. However, no information is available on the neuronal effects of G. neo-japonicum.

The present work reports the study of neuritogenic effects of aqueous extracts of medicinal mushrooms basidiocarps, namely $H$. erinaceus, G. lucidum, G. neo-japonicum and G. frondosa on PC-12 cells. Furthermore, the effects of cellular signaling pathways, MEK/ERK1/2 and PI3K/Akt in the potentiation of neuritogenic activity in PC-12 cells by using specific pharmacological inhibitors were investigated.

\section{Methods}

\section{Materials and chemicals}

The H. erinaceus (KLU-M 1232) and G. lucidum (KLU$M$ 1233) basidiocarps were obtained from Ganofarm in Tanjung Sepat, Selangor. Ganoderma neo-japonicum (KLU-M 1231) basidiocarps were collected from a forest in Ulu Grik, Perak and G. frondosa basidiocarps (KLU$M$ 1229) were purchased from a hypermarket in Selangor, Malaysia. The mushrooms were identified and authenticated by experts in the Mushroom Research Centre, University of Malaya. Voucher specimens are deposited in the University of Malaya herbarium (KLU-M). Rat pheochromocytoma (PC-12Adh) cell line was purchased from American Type Culture Collection (ATCC; Rockville, MD, USA; Catalogue Number: CRL-1721.1). Kaighn's Modification of Ham's F-12 Medium (F-12 K medium), NGF-7S from murine submaxillary gland, 3(4,5-dimethythiazol-2-yl)-2,5-diphenyltetrazolium bromide (MTT), phosphate buffered saline (PBS), dimethyl sulfoxide (DMSO), MEK inhibitor (U0126, PD98059), PI3K inhibitor (LY294002), anti-neurofilament 200 (NF200) antibody produced in rabbit and Anti-Rabbit IgGFluorescein isothiocyanate (FITC) antibody produced in sheep were obtained from Sigma Co. (St. Louis, MO, USA). ProLong ${ }^{\circ}$ Gold Antifade Reagent with DAPI (4-6Diamidino-2-phenylindole) was purchased from Life Technologies Corporation (California, USA). Fetal 
bovine serum (FBS) and horse serum (HS) were purchased from PAA Laboratories (Cölbe, Germany).

\section{Preparation of aqueous extracts}

The aqueous extracts were prepared according to Eik et al. [15]. Briefly, the fresh basidiocarps of $H$. erinaceus and G. frondosa were sliced, weighed and freeze-dried while G. lucidum and G. neo-japonicum were air dried. The dried basidiocarps were then ground into powder by a Waring commercial blender. The powder was then soaked in distilled water at a ratio of 1:20 (w/v) and $150 \mathrm{rpm}$ at room temperature. After $24 \mathrm{~h}$, the mixture was double boiled in a water bath for $30 \mathrm{~min}$ and after cooling was filtered through Whatman no. 4 filter paper. The resulting aqueous extracts were freeze-dried and kept at $-20^{\circ} \mathrm{C}$ prior to use.

\section{In vitro cell culture}

The rat pheochromocytoma (PC-12Adh) cells were sustained in ATCC formulated F-12 $\mathrm{K}$ medium and supplemented with $15 \%(\mathrm{v} / \mathrm{v})$ of heat-inactivated HS and $2.5 \%(\mathrm{v} / \mathrm{v})$ of heat-inactivated FBS with final $\mathrm{pH} 6.8$ 7.2. The cells were subcultured every 2 to 3 days and incubated at $37 \pm 2^{\circ} \mathrm{C}$ in a $5 \% \mathrm{CO}_{2}$-humidified incubator.

\section{Cell viability and cytotoxicity assay}

Cell viability was assessed by the mitochondrialdependent reduction of MTT to purple formazan. PC-12 cells were plated in 96-well plates at a density of $5 \times 10^{3}$ cells/well and incubated overnight at $37^{\circ} \mathrm{C}$ in a $5 \% \mathrm{CO}_{2}$-humidified incubator. Then, the aqueous extracts $(0-2500 \mu \mathrm{g} / \mathrm{ml})$ were added into the cells. After $48 \mathrm{~h}$ of incubation, $20 \mu \mathrm{l}$ of MTT $(5 \mathrm{mg} / \mathrm{ml})$ in PBS buffer ( $\mathrm{pH}$ 7.4) was added into each well and incubated at $37^{\circ} \mathrm{C}$ for $4 \mathrm{~h}$. Subsequently, the supernatant was carefully discarded by aspiration, and $100 \mu \mathrm{l}$ of DMSO was then added into each well to dissolve the MTT formazan crystals, mixed thoroughly and incubated for $15 \mathrm{~min}$. The extent of the reduction of MTT was determined by measurement of the absorbance at $540 \mathrm{~nm}$ with $690 \mathrm{~nm}$ as background absorbance with an ELISA microplate reader (Sunrise, Tecan, Austria). The complete F-12 K medium was the blank, and cells incubated in the medium only were denoted as the negative control.

\section{Neurite outgrowth stimulation assay}

Cells were plated in 12-well plates at a density of $5 \times 10^{3}$ cells per well in complete F-12 K medium. The cells were treated with freshly prepared aqueous extracts at various concentrations ranged from 25 to $100 \mu \mathrm{g} / \mathrm{ml}$ (w/v). Eik et al. [15] reported that $50 \mathrm{ng} / \mathrm{ml}(\mathrm{w} / \mathrm{v})$ of NGF-7S from murine submaxillary gland was the optimum concentration for neuritogenesis in $\mathrm{PC}-12$ cells. In the present study, cells treated with $50 \mathrm{ng} / \mathrm{ml}$ (w/v) of NGF or $50 \mu \mathrm{g} / \mathrm{ml}(\mathrm{w} / \mathrm{v})$ of $H$. erinaceus served as positive controls. Cells in complete $\mathrm{F}-12 \mathrm{~K}$ medium without treatment served as a negative control. Assay plates were incubated for $48 \mathrm{~h}$ at $37 \pm 2^{\circ} \mathrm{C}$ in a $5 \% \mathrm{CO}_{2}-$ humidified incubator.

\section{Quantification of neurite outgrowth}

The cell morphology was assessed under an inverted microscope (Nikon Eclipse TS100). Neurite extension of PC-12 cells was regarded as an index of neuritogenesis. Neurite that was double or more the length of the cell body diameter was scored positive for a neurite-bearing cell [14]. The images were captured with a QImaging Go-3 color CMOS Camera (QImaging, Canada) and by the image processor system, Image-Pro Insight (MediaCybernetics, MD). The percentage of differentiated cells was evaluated by scoring the proportion of neurite-positive cells to total cells in randomly 10 selected microscopic fields per well, with an average of 200-300 cells per well.

\section{Treatment with specific inhibitors of signaling pathways} The MEK/ERK1/2 inhibitors (U0126, PD98059) and PI3K/Akt inhibitor (LY294002) were used in this study. Stock solutions $(10 \mathrm{mM})$ of inhibitors were prepared in DMSO and stored at $-20^{\circ} \mathrm{C}$ in the dark. Final concentrations of $10 \mu \mathrm{M}$ of U0126, $30 \mu \mathrm{M}$ of LY294002 and $40 \mu \mathrm{M}$ of PD98059 were prepared by diluting in complete F-12 K medium just before use [16]. Cells were pre-incubated either with or without the inhibitor for $1 \mathrm{~h}$ at $37 \pm 2^{\circ} \mathrm{C}$ in a $5 \% \mathrm{CO}_{2}$-humidified incubator, respectively before the treatment with $50 \mathrm{ng} / \mathrm{ml}(\mathrm{w} / \mathrm{v})$ of NGF or the optimum concentration of each aqueous extract resulting in the neurite outgrowth stimulation assay. Cells were then incubated for $48 \mathrm{~h}$ prior to scoring the neurite-bearing cells.

\section{Immunofluorescence staining of neurofilament}

Immunofluorescence assay was carried out according to Schimmelpfeng et al. [21] with some modifications. Briefly, cells were seeded in 12-well micro-chamber (ibidi, Martinsried, Germany) at a density of $5 \times 10^{3}$ cells per well in complete F-12 K medium. Then, the cells were pre-incubated either with or without the treatment of inhibitors. After $1 \mathrm{~h}$, the cells were treated with the optimum concentration of each aqueous extract result in the neurite outgrowth stimulation assay for $48 \mathrm{~h}$ at $37 \pm 2^{\circ} \mathrm{C}$ in a $5 \% \quad \mathrm{CO}_{2}$ humidified incubator. Subsequently, the cells were fixed with $4 \%$ formalin $(\mathrm{v} / \mathrm{v})$ at room temperature for $20 \mathrm{~min}$. After three washings with PBS, the cells were incubated with anti-NF-200 antibody produced in rabbit (1:80 dilution in blocking buffer) at room 
temperature for $1 \mathrm{~h}$. Then, the cells were incubated with fluorophore-conjugated secondary antibody, antiRabbit IgG-FITC antibody produced in sheep (1:80 dilution in blocking buffer) at room temperature for $1 \mathrm{~h}$ in the dark. Cells were mounted with aqueous mounting medium, ProLong Gold Antifade Reagent with DAPI. Slides were observed under fluorescence illumination using FITC and DAPI filters and images were captured with Nikon's Imaging Software, NISElements.

\section{Statistical analysis}

All the experimental data were expressed as the mean \pm standard deviation (SD). Statistical differences between groups were performed using one-way analysis of variance (ANOVA) of a minimum of three independent experiments and Duncan's multiple range tests (DMRT) $\mathrm{P}<0.05$ was considered to be significant.

\section{Results}

The cells viability and cytotoxic effects of aqueous extracts on PC- 12 cells

All aqueous extracts tested did not exert any detectable cytotoxic effect in PC-12 cells. The survival rates of the cells were decreased in a concentration-dependent manner, G. lucidum (Figure 1a,b), G. neo-japonicum (Figure 1c,d), and G. frondosa (Figure 1e,f). The negative control, cells in complete F-12 K medium only, was considered as $100 \%$ of cell viability. A significant $(\mathrm{p}<0.05)$ stimulation of proliferation was observed at the concentration of $7.81 \mu \mathrm{g} / \mathrm{ml}$ and $15.63 \mu \mathrm{g} / \mathrm{ml}$ of $G$. neojaponicum. The cell viability was significantly $(\mathrm{p}<0.05)$ decreased at the concentration of $62.5 \mathrm{ug} / \mathrm{ml}$ (G. lucidum), $250 \mathrm{ug} / \mathrm{ml}$ (G. neo-japonicum) and 31.25 $\mathrm{ug} / \mathrm{ml}$ (G. frondosa) with the percentage inhibitions of $13.41 \%, 16.57 \%$ and $13.85 \%$, respectively, compared to the negative control. The reduction in the cell number could be a consequence of cell death or the

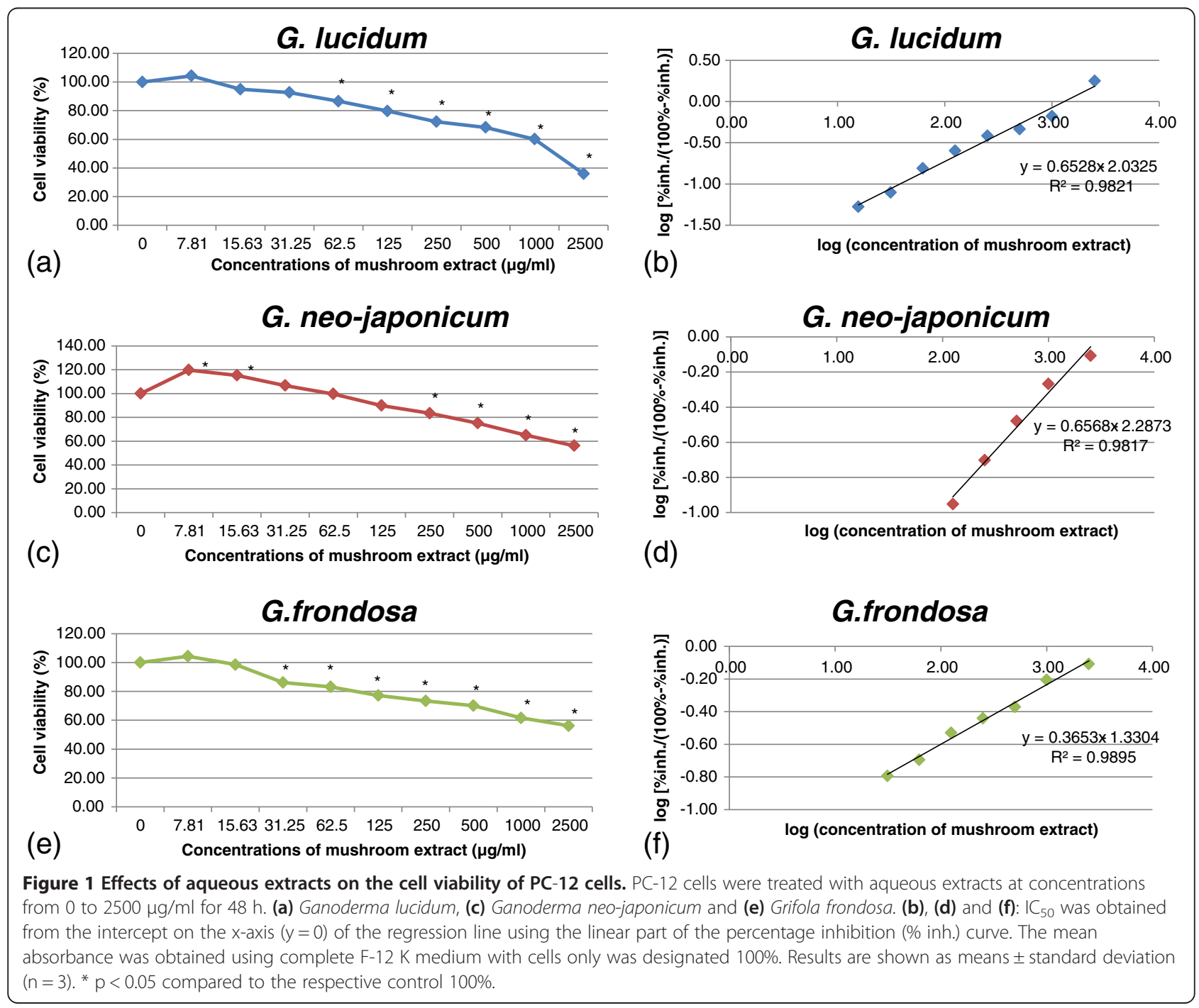




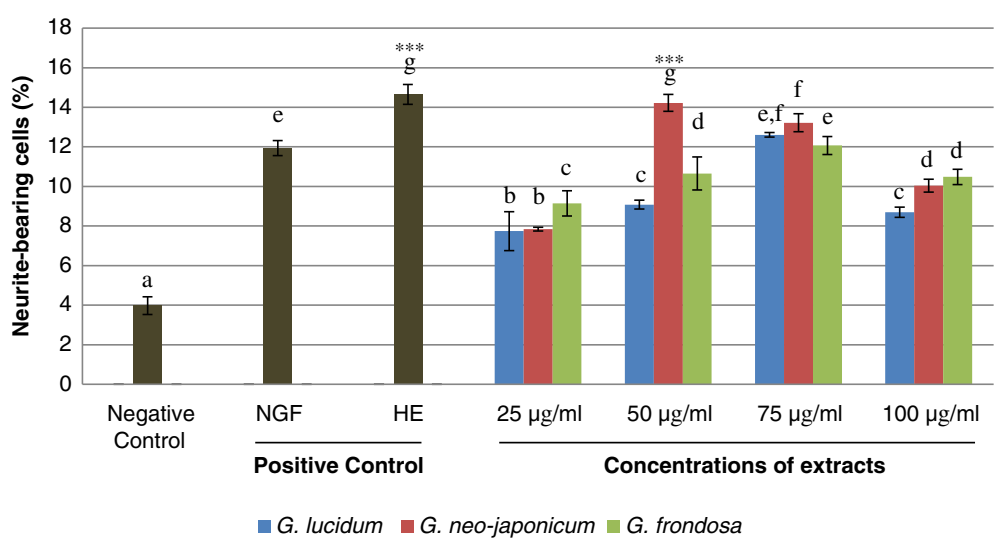

Figure 2 Effects of aqueous extracts on the neuritogenic activity of PC-12 cells. The percentage of neurite-bearing cells of PC-12 cells treated with various concentrations of aqueous extracts ranged from 25 to $100 \mu \mathrm{g} / \mathrm{ml}$. Cells in complete F-12 K medium without treatment served as a negative control. Cells treated with $50 \mathrm{ng} / \mathrm{ml}$ of NGF or $50 \mu \mathrm{g} / \mathrm{ml} \mathrm{of} \mathrm{H}$. erinaceus (HE) served as positive controls. Data were expressed as means \pm standard deviation $(n=3)$. Means with different alphabets shows significant difference $p<0.05 .{ }^{* * *} p<0.001$ compared to NGF.

decrease in the cell division. The required concentration to inhibit the cell growth by $50 \%\left(\mathrm{IC}_{50}\right)$ for aqueous extracts of G. lucidum, G. neo-japonicum and G. frondosa were $1298.71 \mathrm{ug} / \mathrm{ml}, 3037.32 \mathrm{ug} / \mathrm{ml}$ and $4384.68 \mathrm{ug} / \mathrm{ml}$, respectively.

\section{The neuritogenic effect of aqueous extracts on PC-12 cells} All concentrations of aqueous extracts tested showed neuritogenic effects after $48 \mathrm{~h}$ of incubation (Figure 2). Nerve growth factor- and $H$. erinaceustreated cells served as positive controls. The percentage of neurite-bearing cells of G. lucidum-, G. neo-japonicum- and G. frondosa- treated cells were significantly $(p<0.05)$ increased in a concentrationdependent manner. There were significant differences $(\mathrm{p}<$
0.05 ) between the negative control and all concentrations of aqueous extracts tested. Interestingly, the percentage of neurite-bearing cells of aqueous extract of G. neo-japonicum at $50 \mu \mathrm{g} / \mathrm{ml}(14.22 \pm 0.43 \%)$ was significantly higher $(\mathrm{p}<0.05)$ compared to NGF and was comparable to neurite outgrowth stimulation by $H$. erinaceus $(14.66 \pm 0.5 \%)$. Maximum stimulation of neuritogenesis by aqueous extract of G. neojaponicum was achieved at $50 \mu \mathrm{g} / \mathrm{ml}$ with $14.22 \%$ of neuritebearing cells, followed by G. lucidum (12.61\%) and G. frondosa (12.07\%) at a higher concentration of $75 \mu \mathrm{g} / \mathrm{ml}$. There was no significant difference in the percentage of neurite-bearing cells between $50 \mathrm{ng} / \mathrm{ml}$ of NGF $(11.94 \pm 0.38 \%)$ and $75 \mu \mathrm{g} / \mathrm{ml}$ of aqueous extract of G. lucidum $(12.61 \pm 0.11 \%)$ and G. frondosa $(12.07 \pm 0.46 \%)$.

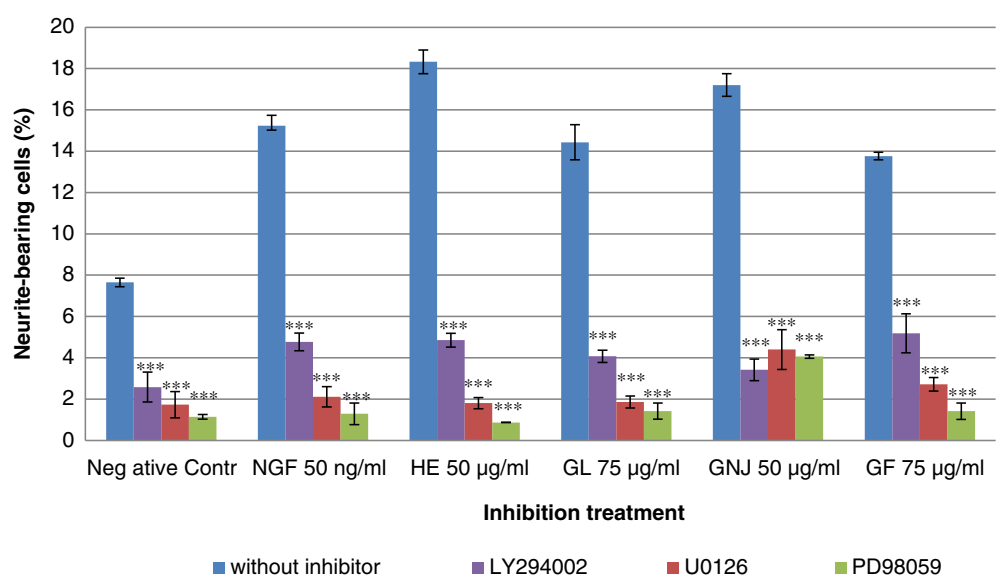

Figure 3 Effects of the specific inhibitors of MEK/ERK1/2 and PI3K on aqueous extracts-stimulated neuritogenesis. PC-12 cells were exposed to U0126, PD98059 and LY294002 for 1 h before the treatment of aqueous extracts of G. lucidum (GL), G. neo-japonicum (GNJ) and G. frondosa (GF). Cells in complete F-12 K medium without treatment served as a negative control. Cells treated with $50 \mathrm{ng} / \mathrm{ml}$ of NGF or $50 \mathrm{\mu g} / \mathrm{ml}$ of $H$. erinaceus (HE) served as positive controls. A control without inhibitor was used in each treatment group. Data were expressed as means \pm standard deviation $(n=3) .{ }^{* *} p<0.001$ compared to respective controls. 


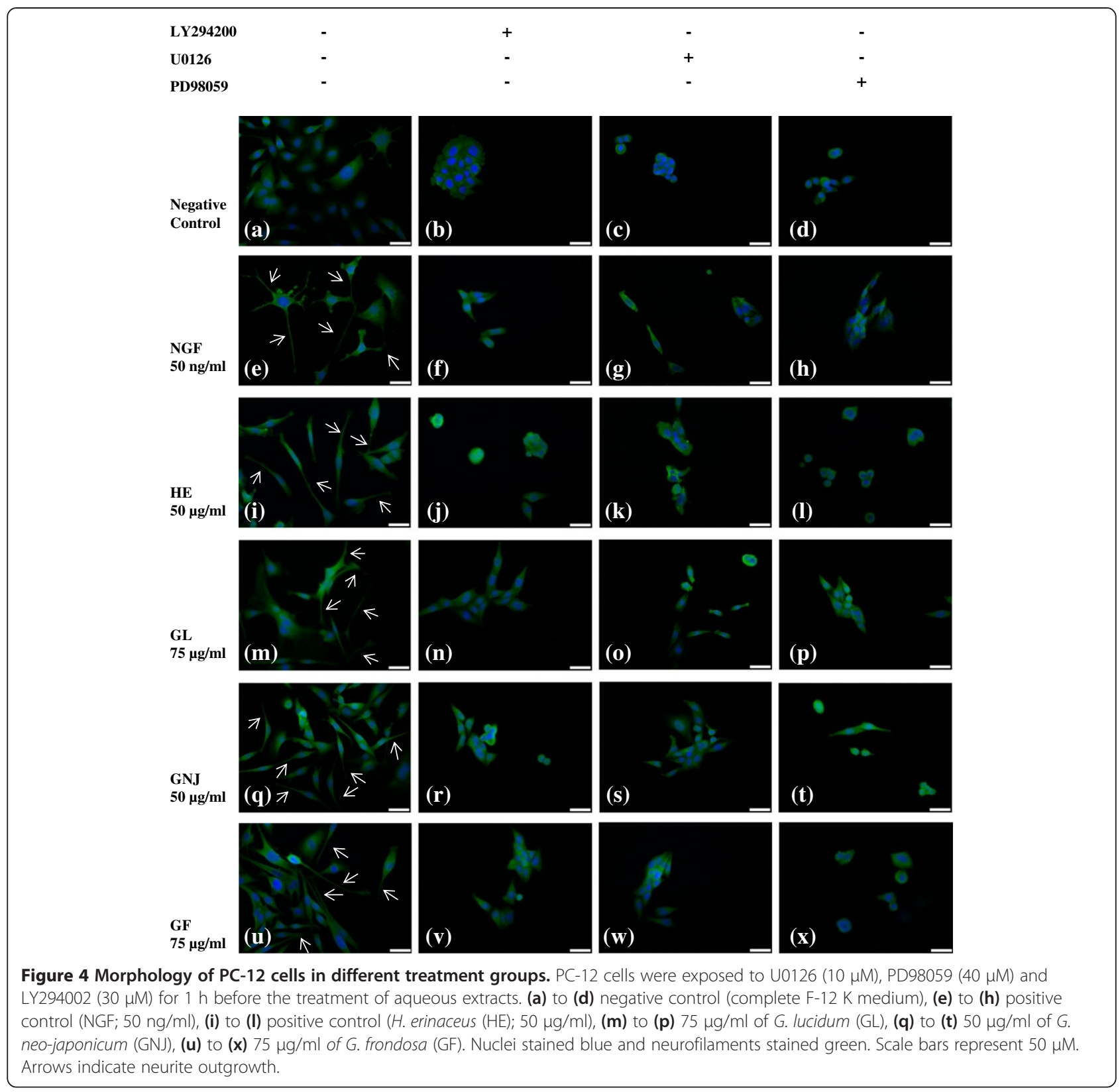

The involvement of MEK/ERK1/2 and PI3K/Akt signaling pathways in aqueous extracts-stimulated neuritogenesis The MEK/ERK1/2 inhibitors, U0126 (10 $\mu \mathrm{M})$ and PD98059 $(40 \mu \mathrm{M})$ blocked the neuritogenic activity of aqueous extracts and NGF (Figure 3). The results showed that PD98059 decreased the percentage of neurite-bearing cells by approximately $90.16 \%$ in $G$. lucidum, $76.42 \%$ in G. neo-japonicum and $89.73 \%$ in G. frondosa treated cells compared to each individual control. In the presence of PI3K/Akt inhibitor, LY294002 (30 $\mu \mathrm{M})$, the number of neurite-bearing cells were decreased significantly $(\mathrm{p}<0.001)$. The significant $(\mathrm{p}<$ 0.001 ) reduction of neurite stimulation activities were also observed in the negative control-, NGF- and aqueous extracts of $H$. erinaceus- stimulated neuritogenesis with the addition of the inhibitors. These data suggest that activation of MEK/ERK1/2 and PI3K/Akt signaling pathways are involved in aqueous extracts-stimulated neuritogenesis in PC-12 cells.

The effect of MEK/ERK1/2 and PI3K/Akt inhibitors on neuronal morphology visualized by immunofluorescence staining

To examine the pattern of neuritogenesis further, PC12 cells were stained by immunofluorescence dyes incorporated with anti-NF-200 antibody. PC-12 cells 


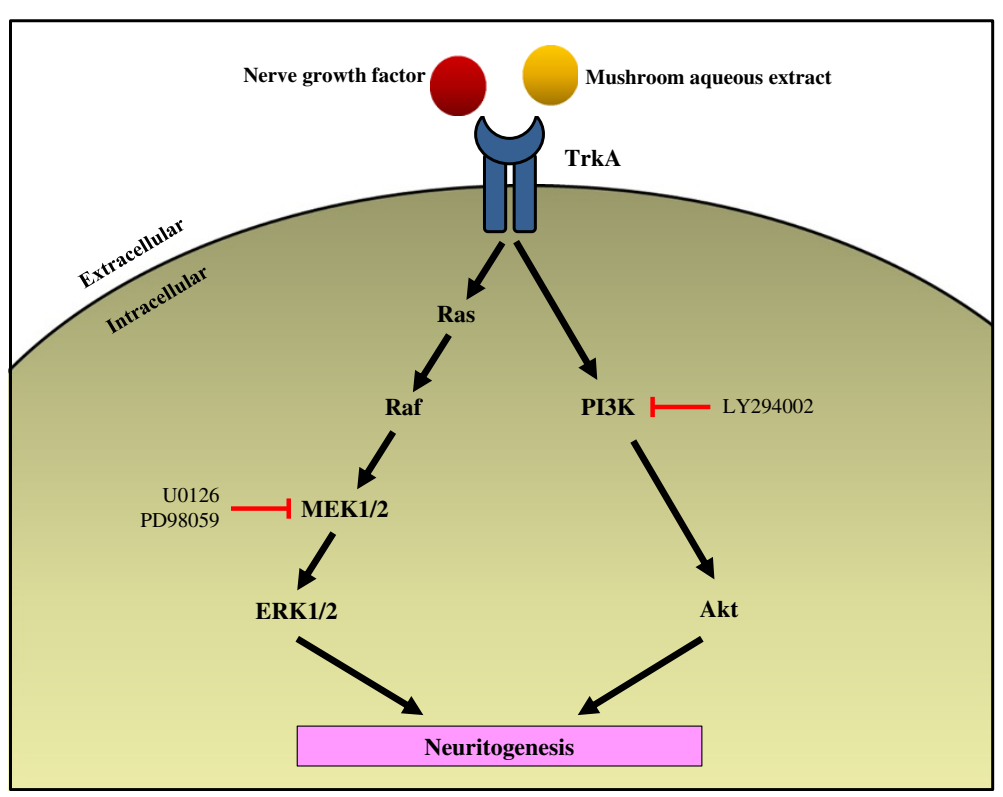

Figure 5 Hypothetic mechanisms of NGF and mushroom aqueous extracts in promoting neuritogenesis in PC-12 cells. Both nerve growth factor and aqueous extracts bind to tyrosine receptor, TrkA and initiate two major signaling pathways, the MEK/ERK1/2 and PI3K/Akt pathways. Activation of MEKJERK1/2 and PI3K/Akt cascade promotes neuritogenesis of PC-12 cells. In the present study, the MEK/ERK1/2 inhibitors (U0126, PD98059) and PI3K/Akt inhibitor (LY294002) blocked the neuritogenic activity of NGF and aqueous extracts. Therefore, based on the present findings, the activation of MEK/ERK1/2 and PI3K/Akt signaling pathways are needed for the NGF and aqueous extracts in promoting neuritogenesis.

nuclei were stained blue by DAPI and neurofilaments were stained green by anti-NF-200 labeled with FITC. The cells were pre-treated, with or without specific inhibitors, prior to the addition of the aqueous extracts and incubated for $48 \mathrm{~h}$. In the negative control, the cells are relatively small and rounded with few visible neurites (Figure 4a). With the treatment of $50 \mathrm{ng} / \mathrm{ml}$ of NGF, $50 \mu \mathrm{g} / \mathrm{ml}$ of $H$. erinaceus, $75 \mu \mathrm{g} / \mathrm{ml}$ of G. lucidum, $50 \mu \mathrm{g} / \mathrm{ml}$ of $G$. neo-japonicum and $75 \mu \mathrm{g} / \mathrm{ml}$ of $G$. frondosa, the cells were larger and elongated. Cells also exhibited neurite extensions that were double the length of the cell body diameter (Figure 4e, 4i, 4m, 4q, 4u). However, some morphological changes in neuronal differentiation were observed in the treatment of U0126, PD98059 and LY294002 inhibitors. The inhibitors blocked the neuritogenic activity of aqueous extracts and NGF and caused shrunken and rounded cell bodies without noticeable neurite extension. These results suggest that the activation of MEK/ERK1/2 and PI3K/Akt signaling pathways are needed for the NGF and aqueous extracts in promoting neuritogenesis.

\section{Discussion}

In the present study, PC-12Adh cell line was utilized as a model system to investigate the cytotoxicity, neuritogenic activity and elucidate the underlying mechanisms of aqueous extracts of medicinal mushrooms basidiocarps, namely G. lucidum, G. neo-japonicum and G. frondosa. The PC-12 cell line is established from rat adrenal pheochromocytoma (adrenal medullary tumour) [22] and has been extensively used as a model to investigate the neuronal differentiation, proliferation and survival [23]. With the addition of NGF, PC-12 cells are able to differentiate into sympathetic neuron-like phenotypes characterized by neurite outgrowth and the expression of several neuron-specific proteins [22,24]. Nerve growth factor is crucial for the survival, developmental and differentiation of the central and peripheral neurons $[25,26]$. The neurotrophic effect of NGF is transduced by high affinity tyrosine receptor TrkA [27], the NGF receptor, and then it activates several signaling pathways via intracellular signaling molecules that include Ras [28], PI3K [26,29], ERK [30] and p38 MAPK [31].

Aqueous extraction has been the most commonly used method for the isolation of bioactive polysaccharides from mushrooms such as glucans [10,32]. According to Cheung et al. [18], the extract of Ganoderma contained polysaccharides that possessed neuroactivity. It had been reported that crude aqueous extract of Tremella fuciformis (white jelly mushroom) possessed neuritogenic effects in vitro and anti-amnesic effects in vivo [33]. According to Lin et al. [34], treatment with the water extract of G. lucidum and G. neo-japonicum showed antioxidant effect on free radical scavenging activity and hepatoprotective effect against CCl4-induced liver injury. Aqueous extraction is 
believed to have lower cytotoxic effect compared to most of the organic solvent. In this study, medicinal mushrooms were extracted by water, in conjunction with the traditional use of mushrooms as part of TCM. In addition, water is non-toxic to cells. From data obtained in this study, the $\mathrm{IC}_{50}$ value of cytotoxic activity of G. lucidum, G. neo-japonicum and G. frondosa were approximately 17-, 60- and 58-fold higher than their optimum concentration that stimulated neuritogenesis. Further, the results indicated that the aqueous extracts of all tested mushrooms were not cytotoxic to PC-12 cells.

The results suggested that all aqueous extracts tested caused a marked stimulation of neuritogenesis in PC12 cells and they appeared to be comparably active with the neuritogenic effects in vitro of NGF. Therefore, the aqueous extracts of G. lucidum, G. neo-japonicum and G. frondosa may possess NGF-like bioactive compounds that mimic the neuroactivity of NGF for neuronal survival, development and differentiation. The aqueous extract of G. neo-japonicum triggered maximal stimulation of neuritogenesis at a lower concentration compared to G. lucidum and G. frondosa that act at a higher concentration. Neuritogenic activity of higher basidiomycetes other than G. neo-japonicum, $G$. lucidum and G. frondosa has also been reported. These included H. erinaceus [4,35], Sarcodon scabrosus [36], Sarcodon cyrneus [37,38], Termitomyces albuminosus [39,40] and Cordyceps militaris [41]. Shi et al. [36] reported that cyathane diterpenoids isolated from S. scabrosus showed significant neuritogenic activity in combination with $20 \mathrm{ng} / \mathrm{mL}$ of NGF in PC-12 cells after $24 \mathrm{~h}$ treatment. The extract of $C$. militaris stimulated neuritogenesis, enhanced neuronal functions of Neuro2A mouse neuroblastoma cells (in vitro) and improved cognitive behaviour that related to memory ability (in vivo) [41].

Our findings illustrated the potential cellular signaling pathways involved in aqueous extracts-stimulated neuritogenesis, namely MEK/ERK1/2 and P13K/Akt that are important in regulating growth and differentiation of PC-12 cells. Specific inhibitors of MEK/ERK1/ 2 and P13K/Akt could attenuate the ability of aqueous extracts to stimulate neuritogenesis in PC-12 cells. The MEK/ERK and PI3K/Akt signaling pathways can be activated by NGF to stimulate neurite extension and branching of neuronal cells [42-45]. Vaudry et al. [30] reported that the activation of MEK/ERK signaling pathway is necessary for neuritogenesis, in this case the neuronal differentiation in PC-12 cells by NGF. Inhibition of PI3K in PC-12 cells will avert NGF-stimulated neurite elongation [25], promote cell protective effect and cell survival [46].

In this study, the potentiation of aqueous extractsstimulated neuritogenesis was blocked by U0126, PD98059 and LY294002. Therefore, the MEK/ERK and PI3K/Akt- dependent signaling pathways play a crucial role in the neuritogenic effect of medicinal mushrooms (Figure 5). This is in agreement with a previous study by Phan et al. [16], documented that MEK/ERK and PI3K/Akt signaling pathways were involved in neuritogenesis stimulated by extracts of $P$. giganteus. Some studies have shown the involvement of MAPK cascade in neuritogenesis. Extracts of Ganoderma [18] and lysophosphatidylethanolamine, a neuroactive compound isolated from G. frondosa [20] activated the MAPK cascade through the MEK/ERK1/2 phosphorylation of PC12 cells.

Neurofilament staining by immunofluorescence served as firm support to the observation that aqueous extractsstimulated neuritogenesis. Neurofilament is a neuronspecific protein that serves as a major component of the cytoskeleton that supporting the axon cytoplasm. It is a useful indicator of PC-12 cell differentiation [21]. The images showed clear morphological differences between the inhibitor-treated and non-inhibitor-treated groups. The addition of the MEK/ERK or PI3K/Akt inhibitors blocked the neuritogenesis of $\mathrm{PC}-12$ cells and the neurite outgrowth of the NGF- and aqueous extracts-stimulated PC-12 cells.

Besides MEK/ERK1/2 and PI3K/Akt, other mechanisms may still be addressed for a comprehensive understanding of neuritogenic activity. The interaction between MEK/ERK and PI3K/Akt signaling pathways determined by flow cytometry or immunoblot analysis will be proposed for elucidation of mechanisms involved in the neuritogenic activity of the three selected mushrooms.

\section{Conclusions}

Our findings suggested that all the medicinal mushrooms tested possessed neuritogenic activity without cytotoxic effect. The MEK/ERK1/2 and PI3K/Akt signaling pathways may play a role in the neuritogenic activity of the mushrooms. The precise mechanism underlying this activity remains to be investigated.

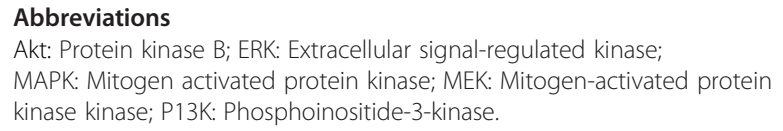

\section{Competing interests}

The authors declare that they have no competing interests.

\section{Authors' contributions}

SLSS carried out the experiment, drafted the manuscript, engaged in data acquisition and data interpretation. MN participated in the acquisition of funding and editing of the manuscript. PD and KHW were involved in the design of the study and manuscript editing. VS provided the grant, was involved in coordinating and monitoring of research, and manuscript editing. All authors read and approved the final manuscript.

\section{Acknowledgements}

The authors thank University of Malaya for grants PG110-2012B, TA039-2012A, J-21001-76536, Ministry of Higher Education for the High Impact Research (HIR) grant, F000002-21001 and Dr. Daniel L. Thomas for English editing. 


\section{Author details}

'Mushroom Research Centre, Faculty of Science, University of Malaya, 50603 Kuala Lumpur, Malaysia. ${ }^{2}$ Institute of Biological Sciences, Faculty of Science, University of Malaya, 50603 Kuala Lumpur, Malaysia. ${ }^{3}$ Department of Anatomy, Faculty of Medicine, University of Malaya, 50603 Kuala Lumpur, Malaysia.

Received: 18 January 2013 Accepted: 28 June 2013

Published: 4 July 2013

\section{References}

1. Acosta D, Wortmann M: World Alzheimer report 2009. In In Alzheimer's Disease International. Edited by Prince M, Jackson J. London: Alzheimer's Disease International; 2009:1-92.

2. Burns A, lliffe S: Alzheimer's disease. BMJ 2009, 338:467-471.

3. More SV, Koppula S, Kim IS, Kumar H, Kim BW, Choi DK: The role of bioactive compounds on the promotion of neurite outgrowth. Molecules 2012, 17:6728-6753.

4. Ma BJ, Shen JW, Yu HY, Ruan Y, Wu TT, Zhao X: Hericenones and erinacines: stimulators of nerve growth factor (NGF) biosynthesis in Hericium erinaceus. Mycology 2010, 1(2):92-98.

5. Liao KK, Wu MJ, Chen PY, Huang SW, Chiu SJ, Ho CT, Yen JH: Curcuminoids promote neurite outgrowth in PC12 cells through MAPK/ERK- and PKCdependent pathways. J Agric Food Chem 2012, 60:433-443.

6. D'Ambrosi N, Cavaliere F, Merlo D, Milazzo L, Mercanti D, Volonte C: Antagonists of $\mathrm{P} 2$ receptor prevent NGF-dependent neuritogenesis in PC12 cells. Neuropharmacology 2000, 39:1083-1094.

7. Hefti F, Weiner WJ: Nerve growth factor and Alzheimer's disease. Ann Neurol 1986, 20(3):275-281.

8. Connor B, Dragunow M: The role of neuronal growth factors in neurodegenerative disorders of the human brain. Brain Res Rev 1998, 27:1-39.

9. Granholm AC, Albeck D, Bäckman C, Curtis M, Ebendal T, Friden P, Henry M, Hoffer B, Kordower J, Rose GM, Söderström S, Bartus RT: A non-invasive system for delivering neural growth factors across the blood-brain barrier: a review. Rev Neurosci 1998, 9(1):31-55.

10. Wasser SP: Medicinal mushrooms as a source of antitumor and immunomodulating polysaccharides. Appl Microbiol Biotechnol 2002, 60:258-274.

11. Wasser SP, Weis AL: Therapeutic effects of substance ocuring in higher basidiomycetes mushrooms: A modern perspective. Crit Rev Immunol 1999, 19(1):65-96

12. Wong KH, Naidu M, David P, Abdulla MA, Abdullah N, Kuppusamy UR, Sabaratnam V: Peripheral nerve regeneration following crush injury to rat peroneal nerve by aqueous extract of medicinal mushroom Hericium erinaceus (Bull.: Fr) Pers. (Aphyllophoromycetideae). Evid Based Complement Alternat Med 2011, 2011. doi:10.1093/ecam/neq062. Article ID 580752):10.

13. Wong KH, Naidu M, David RP, Abdulla MA, Abdullah N, Kuppusamy UR, Sabaratnam V: Functional recovery enhancement following injury to rodent peroneal nerve by lions mane mushroom, Hericium erinaceus (Bull.: Fr.) Pers. (Aphyllophoromycetideae). Int J Med Mushrooms 2009, 11(3):225-236.

14. Wong KH, Sabaratnam V, Abdullah N, Naidu M, Keynes R: Activity of aqueous extracts of lions mane mushroom Hericium erinaceus (Bull.: Fr.) Pers. (Aphyllophoromycetideae) on the neural cell line NG108-15. Int J Med Mushrooms 2007, 9(1):57-65.

15. Eik LF, Naidu M, David P, Wong KH, Tan YS, Sabaratnam V: Lignosus rhinocerus (Cooke) Ryvarden: A medicinal mushroom that stimulates neurite outgrowth in PC-12 cells. Evid Based Complement Alternat Med 2012. doi:10.1155/2012/320308. (Article ID 320308):7.

16. Phan CW, Wong WL, David P, Naidu M, Sabaratnam V: Pleurotus giganteus (Berk.) Karunarathna \& K.D. Hyde: Nutritional value and in vitro neurite outgrowth activity in rat pheochromocytoma cells. BMC Complement Altern Med 2012, 12(102):12-102. doi:10.1186/1472-6882-12-102.

17. Paterson RRM: Ganoderma - A therapeutic fungal biofactory. Phytochemistry 2006, 67:1985-2001.

18. Cheung WMW, Hui WS, Chu PWK, Chiu SW, Ip NY: Ganoderma extract activates MAP kinases and induces the neuronal differentiation of rat pheochromocytoma PC12 cells. FEBS Lett 2000, 486(3):291-296.
19. Hsieh FG, Yeh ZY: Cultural and physiological studies of Ganoderma neojaponicum and G. zonatum. BioFormosa 2004, 39(1):23-32.

20. Nishina A, Kimura H, Sekiguchi A, Fukumoto RH, Nakajima S, Furukawa S: Lysophosphatidylethanolamine in Grifola frondosa as a neurotrophic activator via activation of MAPK. J Lipid Res 2006, 47(7):1434-1443.

21. Schimmelpfeng J, Weibezahn KF, Dertinger H: Quantification of NGFdependent neuronal differentiation of PC-12 cells by means of neurofilament-L mRNA expression and neuronal outgrowth. J Neurosci Methods 2004, 139(2):299-306.

22. Greene LA, Tischler AS: Establishment of a noradrenergic clonal line of rat adrenal pheochromocytoma cells which respond to nerve growth factor. Proc Natl Acad Sci 1976, 73(7):2424-2428.

23. Teng KK, Angelastro JM, Cunningham ME, Greene LA: Cultured PC12 cells: a model for neuronal function, differentiation, and survival. In Cell Biology: A laboratory Handbook. 3rd edition. Edited by Celis JE. USA: Elsevier Science; 2006:171-176.

24. Itoh K, Ishima T, Kehler J, Hashimoto K: Potentiation of NGF-induced neurite outgrowth in PC12 cells by papaverine: Role played by PLC- $\gamma$, IP3 receptors. Brain Res 2011, 1377:32-40.

25. Klesse LJ, Meyers KA, Marshall CJ, Parada LF: Nerve growth factor induces survival and differentiation through two distinct signaling cascades in PC12 cells. Oncogene 1999, 18:2055-2068.

26. Jackson TR, Blader IJ, Hammonds-Odie LP, Burga CR, Cooke F, Hawkins PT, Wolf AG, Heldman KA, Theibert AB: Initiation and maintenance of NGFstimulated neurite outgrowth requires activation of a phosphoinositide 3-kinase. J Cell Sci 1996, 109:289-300.

27. Patapoutian A, Reichardt LF: Trk receptors: mediators of neurotrophin action. Neurobiology 2001, 11:272-280.

28. Qiu MS, Green SH: NGF and EGF rapidly activate p21 ras in PC12 cells by distinct, convergent pathways involving tyrosine phosphorylation. Neuron 1991, 7(6):937-946.

29. Tyson DR, Larkin S, Hamai Y, Bradshaw RA: PC12 cell activation by epidermal growth factor receptor: role of autophosphorylation sites. Int. J. Devl. Neuroscience 2003, 21(2003):63-74.

30. Vaudry D, Stork PJS, Lazarovici P, Eiden LE: Signaling pathways for PC12 cell differentiation: making the right connections. Science 2002, 296:1648-1649.

31. Washio A, Kitamura C, Jimi E, Terashita M, Nishihara T: Mechanisms involved in suppression of NGF-induced neuronal differentiation of PC12 cells by hyaluronic acid. Exp Cell Res 2009, 315(2009):3036-3043.

32. Daba AS, Ezeronye OU: Anti-cancer effect of polysaccharides isolated from higher basidiomycetes mushrooms. Afr J Biotechnol 2003, 12(2):672-678

33. Kim JH, Ha HC, Lee MS, Kang Jl, Kim HS, Lee SY, Pyun KH, Shim I: Effect of Tremella fuciformis on the Neurite Outgrowth of PC12h Cells and the improvement of memory in rats. Biol Pharm Bull 2007, 30(4):708-714.

34. Lin JM, Lin CC, Chen MF, Ujiie T, Takada A: Radical scavenger and antihepatotoxic activity of Ganoderma formosanum, Ganoderma lucidum and Ganoderma neo-japonicum. J Ethnopharmacology 1995, 47(1995):33-41.

35. Mori K, Obara Y, Hirota M, Azumi Y, Kinugasa S, Inatomi S, Nakahata N: Nerve growth factor-inducing activity of Hericium erinaceus in 1321 N1 human astrocytoma cells. Biol Pharm Bull 2008, 31(9):1727-1732.

36. Shi XW, Liu L, Gao JM, Zhang AL: Cyathane diterpenes from Chinese mushroom Sarcodon scabrosus and their neurite outgrowth-promoting activity. European J Med Chem 2011, 46(7):3112-3117.

37. Marcotullio MC, Pagiotti R, Maltese F, Oball-Mond Mwankie GN, Hoshino T, Obara Y, Nakahata N: Cyathane diterpenes from Sarcodon cyrneus and evaluation of their activities of neuritegenesis and nerve growth factor production. Bioorg Med Chem 2007, 15:2878-2882.

38. Marcotullio MC, Pagiott R, Maltese F, Obara Y, Hoshino T, Nakahata N, Curini M: Neurite outgrowth activity of cyathane diterpenes from Sarcodon cyrneus, cyrneines A and B. Planta Med 2006, 72:819-823.

39. Qi J, Ojika M, Sakagami Y: Termitomycesphins A-D, novel neuritogenic cerebrosides from the edible Chinese mushroom Termitomyces albuminosus. Tetrahedron 2000, 56(32):5835-5841.

40. Qi J, Ojika M, Sakagami Y: Neuritogenic cerebrosides from an edible Chinese mushroom. Part 2: Structures of two additional termitomycesphins and activity enhancement of an inactive cerebroside by hydroxylation. Bioorg Med Chem 2001, 9(8):2171-2177. 
41. Lee B, Park J, Park J, Shin HJ, Kwon S, Yeom M, Sur B, Kim S, Kim M, Lee H, Yoon SH, Hahm DH: Cordyceps militaris improves neurite outgrowth in Neuro2a cells and reverses memory impairment in rats. Food Sci Biotechnol 2011, 20(6):1599-1608.

42. Markus A, Zhong J, Snider WD: Raf and Akt mediate distinct aspects of sensory axon growth. Neuron 2002, 35(1):65-76.

43. Yang SH, Liao CC, Chen Y, Syu JP, Jeng CJ, Wang SM: Daidzein induces neuritogenesis in DRG neuronal cultures. J Biomed Sci 2012,

19:80. doi:10.1186/1423-0127-19-80.

44. Faigle R, Song H: Signaling mechanisms regulating adult neural stem cells and neurogenesis. Biochim Biophys Acta 2013, 1830(2):2435-2448.

45. Creedon DJ, Johnson EM, Lawrence JC: Mitogen-activated protein kinaseindependent pathways mediate the effects of nerve growth factor and cAMP on neuronal survival. J Biol Chem 1996, 271(34):20713-20718.

46. Wert MM, Palfrey HC: Divergence in the anti-apoptotic signalling pathways used by nerve growth factor and basic fibroblast growth factor (bFGF) in $\mathrm{PC1} 12$ cells: rescue by bFGF involves protein kinase $\mathrm{C}$ delta. Biochem J 2000, 352:175-182.

doi:10.1186/1472-6882-13-157

Cite this article as: Ling-Sing Seow et al:: Potentiation of neuritogenic activity of medicinal mushrooms in rat pheochromocytoma cells. BMC Complementary and Alternative Medicine 2013 13:157.

\section{Submit your next manuscript to BioMed Central and take full advantage of:}

- Convenient online submission

- Thorough peer review

- No space constraints or color figure charges

- Immediate publication on acceptance

- Inclusion in PubMed, CAS, Scopus and Google Scholar

- Research which is freely available for redistribution

Submit your manuscript at www.biomedcentral.com/submit
C Biomed Central 